\title{
Effect of Lactic Acid and UV Irradiation on the Cassava and Corn Starches
}

\author{
Célia Maria Landi Franco ${ }^{1 *}$, Cristina Ogawa ${ }^{1}$, Taís Rabachini ${ }^{1}$, Thais de Souza Rocha ${ }^{1}$, \\ Marney Pascoli Cereda ${ }^{2}$ and Jay-lin Jane ${ }^{3}$ \\ ${ }^{I}$ Departamento de Engenharia e Tecnologia de Alimentos; Universidade Estadual Paulista; Rua Cristóvão \\ Colombo, 2265; 15054-000; São José do Rio Preto - SP - Brasil. ${ }^{2}$ Centro de Tecnologias para o Agro-Negocio; \\ Universidade Católica Dom Bosco; Av. Tamandaré, s/n; 79117-900; Campo Grande - MS - Brasil. ${ }^{3}$ Iowa State \\ Universiy; Department of Food Science and Human Nutrition, 50011; Ames - IA - USA
}

\begin{abstract}
In this work, the effect of lactic acid and UV irradiation on the physicochemical and structural characteristics of cassava and corn starches was evaluated. Only the modified cassava starch presented baking expansion capacity. From RVA, reduction of viscosity values, greater internal stability and none set back for modified cassava starch were observed. Modified corn starch did not show any peak viscosity. There were no significant differences in DSC thermal properties of treated and native starches. Amylopectin and amylose molecules from both the modified starches displayed some degradation. Molecular weight of cassava amylopectin was mostly preserved, whereas corn amylopectin was evenly attacked through the granule. Nevertheless, the B long branched chains of cassava amylopectin, with $D P \sim 37$, were degraded whereas they were unchanged for corn amylopectin.
\end{abstract}

Key words: starch, photochemical treatment, expansion capacity, structural and physicochemical characteristics

\section{INTRODUCTION}

Starch is a reserve polysaccharide occurring in granular form in higher plants and provides 70$80 \%$ of the calories consumed by human's worldwide (Whistler and BeMiller, 1997). It consists of two polysaccharides, amylose and amylopectin. Both polysaccharides are based on chains of $(1 \rightarrow 4)$-linked $\alpha$-D-glucopyranose residues, but whereas amylose is essentially linear, amylopectin is highly branched. The branch chains are connected by $(1 \rightarrow 6) \alpha$-D-glucosidic linkages (French, 1984; Hizukuri, 1986).

Sour cassava starch (polvilho azedo) is a typical South American product naturally fermented during 15 to 40 days and sun dried. This modified starch has a very interesting characteristic, that is, its great baking expansion capacity and, consequently, high ability to capture the gases and to expand during baking, being able to be used in bread-making products. It is used as basis for biscuit or cheese bread dough, both without using wheat flour, yeast or baking power (Westby and Cereda, 1994). The dough expansion occurs during baking and the baked products present an inflated appearance with good internal alveolar structure (Camargo et al., 1988; Dufour et al., 1996; Demiate et al., 2000; Franco et al., 2002a). Similar to the breads made by traditional bakery process, the products made with sour cassava

*Author for correspondence: celia@ibilce.unesp.br 
starch present, in its interior, a gelatinized starch matrix, responsible for its expansion and texture. The natural fermentation of cassava starch essentially involves lactic flora and lactic acid plays an important role in the baking characteristics of sour cassava starch (Dufour et al., 1996; Mestres and Rouau, 1997). However, just acidification of starch is not enough to increase the expansion during baking (PlataOviedo and Camargo, 1998). According to Mestres and Rouau (1997), lactic acid should influence the bread-making ability of cassava starch through its degradation products. Photochemical reaction involving the starch (Dufour et al., 1996) and the presence of carboxilate groups on cassava starch (Demiate et al., 2000) have been suggested to explain the great baking expansion capacity of this fermented starch.

In laboratory scale, the treatment of cassava starch with lactic acid followed by ultraviolet radiation before artificial drying has also improved its bread-making ability (Demiate et al., 2000; Bertolini et al., 2000), but other starch sources, mainly cereal, did not get the same capacity after the treatment. The structural and functional characteristics of starches submitted to lactic acid action and UV- light as well the influence of the starch source is not completely clear. In this work, cassava and corn starches previously treated with lactic acid and UV radiation before artificial drying were analyzed by their physicochemical and structural characteristics in order to better elucidate the particular baking expansion property of sour cassava starch.

\section{MATERIALS AND METHODS}

\section{Materials}

Native cassava and corn starches were provided by Cargill Industry (São Paulo, SP, Brazil) and two sour cassava starch samples were obtained locally. The samples presented the following $\mathrm{pH}$ values: 5.83 for native cassava starch, 5.20 for native corn starch, 3.94 and 3.91 for the two sour cassava starch samples. Crystalline Pseudomonas isoamylase (EC 3.2.1.68, Hayashibara Shoji, Okayama, Japan) was used as received. Sepharose CL-2B gel was a product of Pharmacia Inc. (Piscataway, NJ, USA), and Biogel P6 was a product of Biorad Laboratories (Hercules, CA,
USA). Other chemicals, all reagent-grade were used without further purification.

\section{Photochemical Treatment}

Native cassava and corn starches were modified as follow: starch samples were treated with $0.24 \mathrm{M}$ lactic acid solution providing starch samples with $45 \%$ final moisture contents. The final lactic acid content was calculated as $2.0 \mathrm{~g} / 100 \mathrm{~g}$ of starch (dry starch basis). The samples were maintained for 30 $\min$ at $30{ }^{\circ} \mathrm{C}$ to homogenization. After that, the acidified starches were distributed on a table of 0.4 $\mathrm{m}^{2}$, in a $5 \mathrm{~cm}$ layer thickness. Over this table at the height of $8 \mathrm{~cm}$ from the material, UV lamps were placed. The lamps were turned on during $10 \mathrm{~min}$ with total energy of $90 \mathrm{~kJ} / 0.4 \mathrm{~m}^{2}$. The samples were revolved throughout the experiment. After the treatment, the starches were dried in a pilot flash drier for $5 \mathrm{sec}$ leaving out the drier with $12 \%$ moisture. The cassava and corn starches submitted to the photochemical treatment presented values of $\mathrm{pH}$ of 3.29 and 3.18, respectively.

\section{Baking Expansion Capacity of Starches}

Baking expansion capacity of the starches was evaluated according to Cereda (1983) by measuring the specific volume of the rolls obtained after baking. The starch dough was prepared with native or modified starches according to a basic formulation: $100 \mathrm{~g}$ starch that was scalded with $40 \mathrm{~mL}$ of a blend of water with fat $(2 \%)$ and salt $(4 \%)$. The components were mixed for $10 \mathrm{~min}$. After that, approximately 40 $\mathrm{mL}$ of water was slowly added until a dough with adequate consistency was obtained. Rolls were formed and baked at $200{ }^{\circ} \mathrm{C}$ for $20 \mathrm{~min}$ in an electric oven. The finished products were tested for appearance, flavor, texture and specific volume. The specific volume $\left(\mathrm{cm}^{3} / \mathrm{g}\right)$ was calculated by seed displacement. Ten rolls of each starch were analyzed.

\section{Pasting Properties of Starches}

Pasting properties of starch samples were obtained using a Rapid Visco Analyzer (RVA-4, Newport Scientific, Australia). A starch suspension in 0.2 $\mathrm{M}$ acetate $(\mathrm{pH} 4.0)$ or phosphate $(\mathrm{pH} 7.0)$ buffer (8\%, dsb, w/w; $28 \mathrm{~g}$ total weight) was equilibrated at $30{ }^{\circ} \mathrm{C}$ for $1 \mathrm{~min}$, heated to $95{ }^{\circ} \mathrm{C}$ at a rate of 6 ${ }^{\circ} \mathrm{C} / \mathrm{min}$, held at $95{ }^{\circ} \mathrm{C}$ for $5.5 \mathrm{~min}$, cooled down to $50{ }^{\circ} \mathrm{C}$ at a rate of $6{ }^{\circ} \mathrm{C} / \mathrm{min}$, and finally held at 50 ${ }^{\circ} \mathrm{C}$ for $2 \mathrm{~min}$. The suspensions were stirred at 160 
rpm throughout the experiment. All the determinations were performed in duplicate.

\section{Thermal Properties of Starches}

Gelatinization properties of starch samples were determined by using a differential scanning calorimeter (DSC-Pyris 1, Perkin Elmer, Norwalk, CT). Starch samples (2 mg, dsb) were weighed in aluminum pans, mixed with distilled water $(6 \mu \mathrm{L})$ and sealed. The weighed samples were kept at room temperature for $2-3 \mathrm{~h}$ to equilibrate and scanned at a rate of $10{ }^{\circ} \mathrm{C} / \mathrm{min}$ over a temperature range of $25-100{ }^{\circ} \mathrm{C}$. An empty pan was used as a reference. All the measurements were performed in triplicate.

\section{Molecular Size Distribution of the Starches by Gel Permeation Chromatography (GPC)}

Starch $(100 \mathrm{mg})$ was dispersed in 90\% DMSO solution $(10 \mathrm{~mL})$ following the procedure of Song and Jane (2000). An aliquot $(2.5 \mathrm{~mL})$ containing $7.5 \mathrm{mg}$ of starch and $1 \mathrm{mg}$ of glucose (as a marker) was loaded onto a column [1.0 (i.d.) $\mathrm{x}$ $70.0 \mathrm{~cm}$ ] packed with Sepharose CL-2B gel following the procedure reported by Wang et al. (1993). The column was eluted in the ascending mode. The eluent consisted of $\mathrm{NaCl}(25 \mathrm{mM})$ and $\mathrm{NaOH}(1 \mathrm{mM})$ with a flow rate of $0.5 \mathrm{~mL} / \mathrm{min}$. Fractions of $2.5 \mathrm{~mL}$ each were collected and subjected to total carbohydrate and amylose content analysis using phenol sulfuric (Dubois et al., 1956) with modifications according to Fox and Robyt (1991), and iodine staining reactions (Juliano, 1971), respectively, to determine the molecular weight distribution of amylopectin and amylose.

\section{Branch Chain Length Distribution of Amylopectin by GPC}

Starch $(100 \mathrm{mg})$ was dispersed in 90\% DMSO solution $(10 \mathrm{~mL})$ following the procedure of Song and Jane (2000). Branch chain length distribution of amylopectins was performed as described by Jane et al. (1992). The starch (40 mg) was precipitated from DMSO solution with ethanol, and dissolved in distilled water $(6.4 \mathrm{~mL})$ by stirring the solution in a boiling water bath for 30 min. An acetate buffer solution $(0.1 \mathrm{M}, 0.8 \mathrm{~mL})$ was added, and the $\mathrm{pH}$ was adjusted to 3.5. Pseudomonas amyloderamosa isoamylase (EC 3.2.1.68, Hayashibara Shoji, Okayama, Japan) (900 units) was added, and the mixture was incubated at $40{ }^{\circ} \mathrm{C}$ for $48 \mathrm{~h}$. After that, the digest was heated in a water bath at $96{ }^{\circ} \mathrm{C}$ for $15 \mathrm{~min}$ to stop the enzyme activity. Branch chain length distribution was analyzed by a Bio-Gel P-6 gel permeation column. Fractions of $2.5 \mathrm{~mL}$ each were collected and subjected to total carbohydrate content analysis using phenol sulfuric (Dubois et al., 1956; Fox and Robyt, 1991). The reducing value of each peak was determined by using the modified Park-Johnson method (Hizukuri et al., 1981). Chain length determinations were repeated at least two times. The average chain length of debranched amylopectin was calculated from the ratio of total carbohydrate/reducing value at the peak fractions.

\section{Branch Chain Length Distribution of Amylopectin by High-Performance Anion- Exchange Chromatography (HPAEC)}

The branch chain length distribution of amylopectin was determined following the method of Wong and Jane (1997). Whole starch samples were debranched using isoamylase and analyzed by high-performance anion-exchange chromatography (Dionex DX-300 system, Sunnyvale, CA) equipped with a post-column amyloglucosidase reactor and a pulsed amperometric detector (HPAEC-ENZ-PAD). An anion-exchange column (CarboPac PA-100 column) and a guard column were used for analysis. A gradient composed of eluent A (100 $\mathrm{mM} \mathrm{NaOH})$ and eluent $\mathrm{B}(100 \mathrm{mM} \mathrm{NaOH}, 300$ $\mathrm{mM} \mathrm{NaNO}$ ) was programmed as follows. At 0 min, the mobile phase consisted of $99 \% \mathrm{~A}$ and $1 \%$ $B$. The concentration of eluent $B$ in mobile phase was linearly increased to $5,8,30$, and $45 \%$ at time intervals of $30,50,160$, and $220 \mathrm{~min}$, respectively. The flow rate of eluent was at 0.5 $\mathrm{mL} / \mathrm{min}$ flow rate through out the analysis.

\section{Iodine Affinity and Amylose Content}

Starch samples were defatted by dispersing starch in $90 \%$ DMSO solution in a boiling water bath with stirring for $1 \mathrm{~h}$ as described by Franco et al. (2002b). Iodine affinities of defatted whole starches were determined as in Kasemsuwan et al. (1995). A potentiometric autotitrator (716 SM Titrino, Brinkmann Instrument, Westbury, NY) was used to measure iodine affinity. Amylose contents were calculated by dividing the iodine affinity of starch by $19.0 \%$ (Takeda and Hizukuri, 1987). 


\section{Statistical Analysis}

All samples were analyzed in duplicate or in triplicate. Statistical analysis was performed using the data analysis tools of Statistics for Windows (v. 5.0, Statsoft, Tulsa, OK). Analysis of variance was conducted using Tukey's studentized range test at the $5 \%$ level.

\section{RESULTS AND DISCUSSION}

\section{Baking Expansion Capacity}

The baking expansion capacity of starch was expressed as the specific volume of the rolls obtained from the starch dough after baking (Table
1). The rolls prepared with native cassava and corn starches did not show baking expansion capacity, presenting very low specific volumes (2.35 and 1.21 , respectively for cassava and corn starches). The rolls prepared with both the commercial sour cassava starch samples presented an inflated appearance, a crumb with typical flavor and alveolar structure, crispy crust and high specific volume $\left(12.10\right.$ and $\left.13.05 \mathrm{~cm}^{3} / \mathrm{g}\right)$, as expected (Franco et al., 2002a). From the samples treated with lactic acid and UV-light, only the rolls prepared with modified cassava starch showed baking expansion ability $\left(8.08 \mathrm{~cm}^{3} / \mathrm{g}\right)$, presenting appearance and texture similar to those shown by the commercial sour cassava starch samples.

Table 1 - Baking expansion characteristics and specific volume* of products elaborated with cassava and corn native and modified starches.

\begin{tabular}{lcccc}
\hline \multicolumn{1}{c}{ Starches } & \multicolumn{2}{c}{ Product characteristics } & $\begin{array}{c}\text { Specific volume } \\
\left(\mathbf{c m}^{\mathbf{3}} / \mathbf{g}\right)\end{array}$ \\
\hline & $\begin{array}{c}\text { Crumb } \\
\text { structure }\end{array}$ & $\begin{array}{c}\text { Flavor and } \\
\text { appearance }\end{array}$ & Crust & \\
\hline Native cassava & Very poor & No characteristic & No crispy & $2.35^{\mathrm{c}}$ \\
Cassava + lactic acid + UV & Alveolar defined & No characteristic & Crispy and fine & $8.08^{\mathrm{b}}$ \\
Fermented cassava starch 1 & Alveolar defined & characteristic & Crispy and fine & $12.10^{\mathrm{a}}$ \\
Fermented cassava starch 2 & Alveolar defined & characteristic & Crispy and fine & $13.05^{\mathrm{a}}$ \\
Native corn & Very poor & No characteristic & No crispy & $1.21^{\mathrm{c}}$ \\
Corn + lactic acid + UV & Very poor & No characteristic & No crispy & $1.33^{\mathrm{c}}$ \\
\hline
\end{tabular}

* Average specific volume of 10 replicates; Values followed by the same letter are not significantly different $(P<0.05)$.

\section{Pasting Properties}

Pasting properties of native and modified starches were determined at $\mathrm{pH} 4.0$ and 7.0 (Table 2). There were differences among the samples, especially in terms of peak viscosity and cooking stability. The photochemical treatment provided the reduction of the viscosity values of cassava starch in both $\mathrm{pH}$ values. In acidic $\mathrm{pH}$, the peak viscosity reduced with the treatment, from 245 to 68 Rapid Visco Units (RVU). Also, the photochemically treated starch displayed greater internal stability and did not show any set back phenomenon during the cooling, on contrary to native cassava starch. These differences were enhanced at neutral $\mathrm{pH}$. The peak viscosity of native cassava starch was increased in $\mathrm{pH} 7.0$, whereas it was deeply reduced for cassava starch submitted to the treatment (from 294 to $36 \mathrm{RVU}$ ). The viscoamilograph profiles of sour cassava starch samples were similar to the photochemically modified cassava starch. These results agreed with those found by Mestres et al. (1997; 2000).

The pasting behavior of corn starch submitted to the photochemical treatment was similar using $\mathrm{pH}$ 4.0 or 7.0. Practically, no peak viscosity was observed and the viscosities were significantly lower than for photochemically modified cassava starch. The results suggested that the photochemical treatment provided degradation and solubilization of starch molecules that were higher for the corn starch.

Bertolini et al. (2000) observed that the acid addition alone decreased the paste viscosity in cassava and corn starches, but the combination of lactic acid addition and UV irradiation was necessary for a higher decrease in the intrinsic viscosity and paste viscosity of both the starches. However, just for cassava starch, this combination (lactic acid plus UV irradiation) provided the increase of expansion volume during the baking of starch dough as also observed in this work. 
Mestres and Rouau (1997), Mestres et al. (1997) and Demiate et al. (2000) suggested that the decrease on the paste viscosity of sour cassava starch was provided by the oxidative modifications such as depolymerization and photo-oxidation of starch molecules due to both action of fermentation and sun drying. The lower viscosity of this product would be related to its higher solubility in hot water, which has been attributed, mainly to higher amylopectin solubilization
(Mestres et al., 1997). Similar effects could occur with cassava starch submitted to the lactic acid and UV-light treatment. On the other hand, Vatanasuchart et al. (2003), studying the action of lactic acid and radiation with different UV wavelengths on the cassava starch suggested that treatment caused a partial depolymerization of amylose molecules and formed a network structure with hydrogen bonding.

Table 2 - Pasting properties of cassava and corn native and modified starches ${ }^{\mathrm{a}}$ in $\mathrm{pH} 4.0$ and 7.0 buffers.

\begin{tabular}{|c|c|c|c|c|c|c|c|c|c|c|}
\hline \multirow{3}{*}{$\begin{array}{c}\text { Starches }^{\mathrm{b}} \\
\mathbf{p H}\end{array}$} & \multirow{2}{*}{\multicolumn{2}{|c|}{$\begin{array}{c}\text { Pasting } \\
\text { Temp. }\left({ }^{\circ} \mathrm{C}\right)\end{array}$}} & \multicolumn{8}{|c|}{ Viscosity (RVU) } \\
\hline & & & \multicolumn{2}{|c|}{ Peak } & \multicolumn{2}{|c|}{$\begin{array}{c}\text { Shear- } \\
\text { Thinning }\end{array}$} & \multicolumn{2}{|c|}{ Final } & \multicolumn{2}{|c|}{ Set back } \\
\hline & 4.0 & 7.0 & 4.0 & 7.0 & 4.0 & 7.0 & 4.0 & 7.0 & 4.0 & 7.0 \\
\hline Native cassava & $68.4^{\mathrm{d}}$ & $72.3^{\mathrm{c}}$ & $245^{b}$ & $294^{\mathrm{a}}$ & $157^{\mathrm{b}}$ & $209^{\mathrm{a}}$ & $147^{\mathrm{a}}$ & $129^{b}$ & $60^{\mathrm{b}}$ & $44^{\mathrm{c}}$ \\
\hline Cassava + lactic acid + UV & $67.6^{\mathrm{d}}$ & $71.5^{\mathrm{c}}$ & $68^{\mathrm{g}}$ & $39^{\mathrm{h}}$ & $56^{\mathrm{g}}$ & $31^{\mathrm{h}}$ & $14^{\mathrm{d}}$ & $8^{\text {de }}$ & $5^{f}$ & $3^{\mathrm{fg}}$ \\
\hline Fermented cassava starch 1 & $64.2^{\mathrm{e}}$ & $67.6^{\mathrm{d}}$ & $167^{\mathrm{c}}$ & $87^{\mathrm{e}}$ & $147^{\mathrm{c}}$ & $82^{\mathrm{e}}$ & $35^{\mathrm{c}}$ & $11^{\mathrm{d}}$ & $12^{\mathrm{e}}$ & $6^{\mathrm{f}}$ \\
\hline Fermented cassava starch 2 & $68.0^{\mathrm{d}}$ & $71.9^{\mathrm{c}}$ & $163^{\mathrm{c}}$ & $79^{f}$ & $139^{\mathrm{d}}$ & $71^{f}$ & $39^{c}$ & $13^{\mathrm{d}}$ & $15^{\mathrm{e}}$ & $6^{\mathrm{f}}$ \\
\hline Native corn & $85.1^{\mathrm{a}}$ & $80.7^{b}$ & $151^{\mathrm{d}}$ & $169^{\mathrm{c}}$ & $68^{\mathrm{f}}$ & $60^{\mathrm{g}}$ & $149^{\mathrm{a}}$ & $148^{\mathrm{a}}$ & $66^{\mathrm{a}}$ & $38^{\mathrm{d}}$ \\
\hline Corn + lactic acid +UV & $81.3^{\mathrm{b}}$ & $81.9^{\mathrm{b}}$ & $9^{i}$ & $8^{\mathrm{i}}$ & $8^{\mathrm{ij}}$ & $5^{\mathrm{j}}$ & $3^{\mathrm{e}}$ & $4^{\mathrm{e}}$ & $2^{\mathrm{fg}}$ & $1^{\mathrm{g}}$ \\
\hline
\end{tabular}

a Averages of two replicates per sample; Values followed by the same letter for each pasting property are not significantly different $(P<0.05)$.

b Sample concentrations are $8 \%, \mathrm{dsb}, \mathrm{w} / \mathrm{w}$.

\section{Thermal Properties}

Thermal properties of native and modified starches are shown in Table 3. Gelatinization temperatures and enthalpy changes of the starches were not significantly altered with the photochemical treatment, with the exception of the onset temperature of the corn starch that reduced after the treatment. Camargo et al. (1988) did not observe any difference between the thermal properties of native and fermented and sun dried cassava starches either. Mestres and Rouau (1997), who worked with fermented starches dried by sun and by oven, also observed similar results between the samples. These results suggested that the crystalline structure of cassava starch was not modified by the acidification and exposition to UV radiation. Vatanasuchart et al. (2003), determining the X-ray diffraction patterns and calculating the relative crystallinity degree of the native and UVlight/acid modified cassava starches, also did not observe any change in their crystalline structures. The lower onset gelatinization temperature shown by the corn starch treated with lactic acid and UVlight could be related to higher amylopectin depolymerization as observed by very low viscosity detected for this sample (Table 2).

Table 3 - Thermal properties ${ }^{a}$ of cassava and corn native and modified starches ${ }^{b}$

\begin{tabular}{lcccc}
\hline \multicolumn{1}{c}{ Starches ${ }^{\mathbf{c}}$} & To $\left({ }^{\circ} \mathbf{C}\right)$ & Tp $\left({ }^{\circ} \mathbf{C}\right)$ & Tc $\left({ }^{\circ} \mathbf{C}\right)$ & $\Delta \mathbf{H}(\mathbf{J} / \mathbf{g})$ \\
\hline Native cassava & $62.34^{\mathrm{c}}$ & $68.23^{\mathrm{b}}$ & $75.60^{\mathrm{ab}}$ & $14.13^{\mathrm{ab}}$ \\
Cassava + lactic acid +UV & $61.80^{\mathrm{c}}$ & $67.84^{\mathrm{b}}$ & $74.44^{\mathrm{b}}$ & $14.72^{\mathrm{ab}}$ \\
Fermented cassava starch 1 & $60.81^{\mathrm{d}}$ & $68.16^{\mathrm{b}}$ & $74.89^{\mathrm{b}}$ & $15.41^{\mathrm{a}}$ \\
Fermented cassava starch 2 & $59.42^{\mathrm{e}}$ & $64.92^{\mathrm{c}}$ & $71.23^{\mathrm{c}}$ & $15.30^{\mathrm{a}}$ \\
Native corn & $66.00^{\mathrm{a}}$ & $71.63^{\mathrm{a}}$ & $76.66^{\mathrm{a}}$ & $10.28^{\mathrm{c}}$ \\
Corn + lactic acid +UV & $64.66^{\mathrm{b}}$ & $70.92^{\mathrm{a}}$ & $76.43^{\mathrm{a}}$ & $11.62^{\mathrm{bc}}$ \\
\hline
\end{tabular}

a To, Tp, Tc: onset, peak and complete temperature (oC), respectively; $\Delta \mathrm{H}$ : enthalpy change (J/g).

$\mathrm{b}$ Averages of at least three replicates; Values followed by the same letter in the same column are not significantly different $(P<$ 0.05 ).

c Starches samples $[\sim 2 \mathrm{mg}$, dsb] and distilled water $[6 \mu \mathrm{L}]$ used for analyses. 


\section{Starch Molecular Size Distribution by GPC}

Sepharose CL 2B gel permeation chromatograms of native and modified starches are shown in Figure 1(a-e). The first peak corresponded to amylopectin. The second one displaying substantial blue value (iodine reaction) corresponded to amylose. The last one was glucose added to mark the end of the elution.

The native cassava starch (Fig. 1a) displayed the amylopectin peak at fraction 24 , corresponding to a volume of $60 \mathrm{~mL}$, whereas the amylose showed a broader peak at fraction $52(\sim 130 \mathrm{~mL})$. There was a light reduction of the total carbohydrates at amylopectin peak for the modified cassava starch (Fig. 1b), suggesting its partial degradation during the treatment. The amylose peak was detected in a higher volume and with a higher blue value response than those from native cassava starch indicating the reduction of molecular weight of this polymer with the treatment. Commercial sour cassava starches used for comparison displayed elution profiles very similar to the cassava starch submitted to lactic acid and UV-light (Fig. 1c, 1d). The native corn starch also showed amylopectin peak being eluted at the void volume of the column. The amylose peak was eluted at fraction 57 (Fig. 1e), confirming the lower molecular weight of this polymer for corn starch when compared to cassava starch (Fig. 1a). According to Swinkels (1985), the polymerization degree of amylose is dependent of its botanical source. Potato and cassava starches showed high molecular weight molecules when compared to corn and wheat starches. The high blue value response at this peak also indicated higher amylose content for corn starch than that of cassava starch.

The corn starch was greatly affected by the treatment (Fig. 1f). The corn amylopectin peak deeply reduced and there was an increase of the intermediate materials between amylopectin and amylose, besides a higher blue value response at amylose peak. In addition, the amylose peak was eluted in a higher volume and was narrower than that of native corn starch indicating the fractions of lower molecular weight as also observed for the modified cassava starch. These results suggested that some of the cassava amylopectin branch chains located in the inner core of the granule were likely protected and only the amorphous areas of branch chains on the periphery of the granules were attacked by the lactic acid and UV-light. Thus, the molecular weight of cassava amylopectin was mostly preserved which provided some viscosity to develop the expansion during baking. On the other hand, the lactic acid and UVlight could have penetrated more easily into the granules of corn starch, and the amylopectin was evenly attacked through the granule. Corn starch displays surface pores and cavities (Fannon et al., 1992; Huber and BeMiller, 2000), and also higher proportions of granules of smaller diameter than cassava starch (Srivastava et al., 1970; Jane et al., 1994; Moorthy, 1994). It was possible that these factors contributed for the lower resistance of this starch to acid and UV treatment.

\section{Branch Chain Length Distributions by GPC}

Branch chain length distributions of debranched amylopectins of native and modified starches are shown in Figure 2. The profiles of native starches displayed three major peaks, besides glucose used as a marker and eluted at the fraction 62 . The first peak, eluted at the void volume of the column, contained mostly amylose molecules and some very long $B$ chains of amylopectin (which could be $\mathrm{B}_{3}$ or longer). The second one corresponded to the long chains of amylopectin $\left(\mathrm{B}_{2}\right)$ and the third one contained short chains (A and $\mathrm{B}$ ) of amylopectin (Kasensuwan et al., 1995). The chain length (CL) from the material collected at the apices of second and third peaks were determined. The average CL of B long chains (second peak) and $A$ and $B$ short chains (third peak) of amylopectin from native cassava starch was 37 and 16, respectively (Fig.2a). The photochemical treatment on this starch affected mainly the B long chains of amylopectin with DP of 37, which were vanished from the chromatogram (Fig. 2b).

Chromatograms of commercial sour cassava starch samples (Fig. 2c, 2d) used for comparison displayed similar profiles to those of the photochemically modified cassava starch, showing just the third peak with A and B short chains. For the corn starch, the chromatograms showed similar profiles between the native and modified starches. The average $\mathrm{CL}$ of $\mathrm{B}$ long chains and $\mathrm{A}$ and $\mathrm{B}$ short chains was 37 and 21, respectively for native corn amylopectin, and 35 and 17, respectively for modified corn amylopectin (Fig. 2e, 2f). 

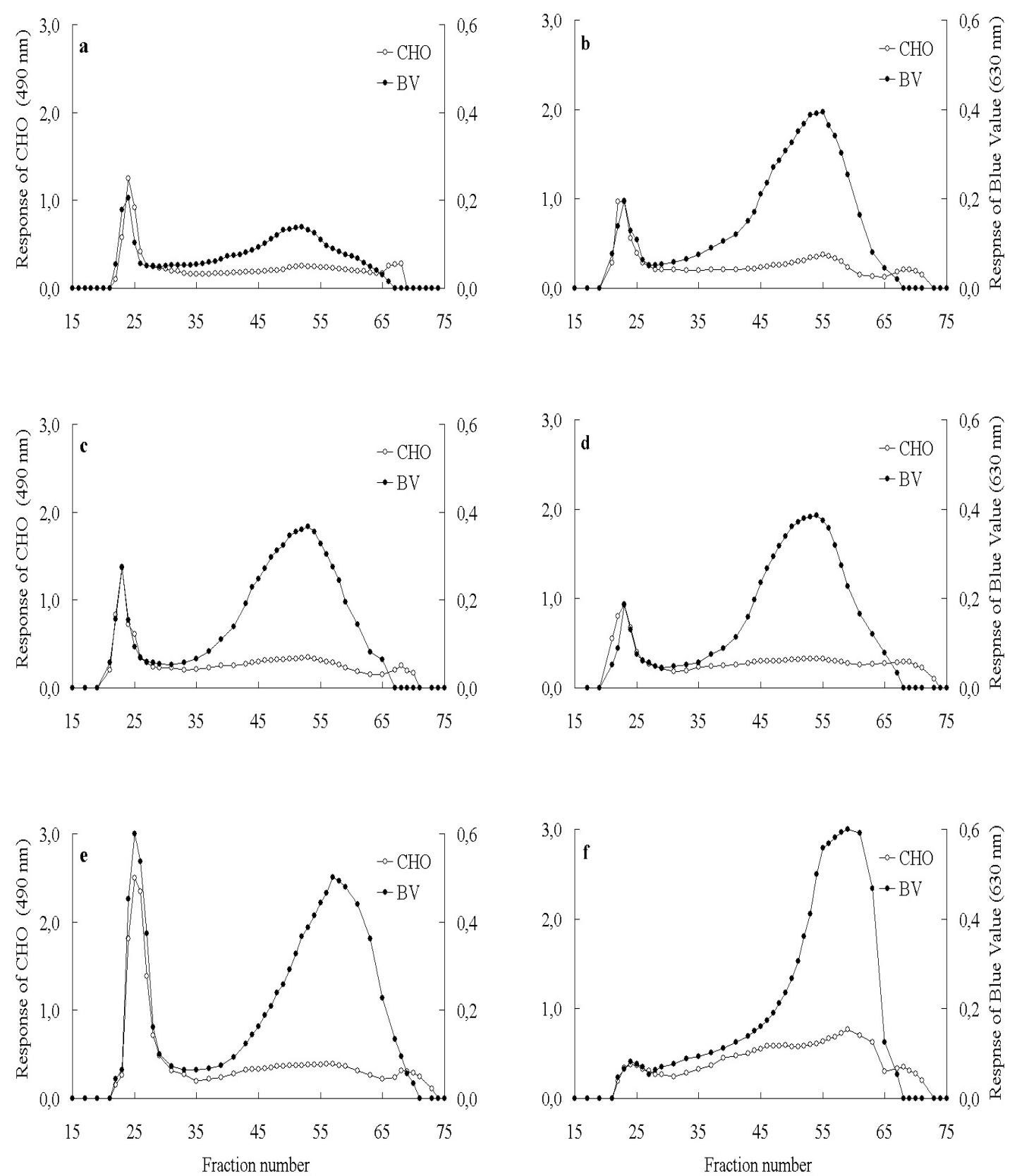

Figure 1 - Elution profiles of cassava and corn starches on Sepharose CL-2B column. a: native cassava; b: cassava + lactic acid + UV; c: commercial fermented cassava starch 1; d: commercial fermented cassava starch 2; e: native corn; f: corn + lactic acid + UV. 

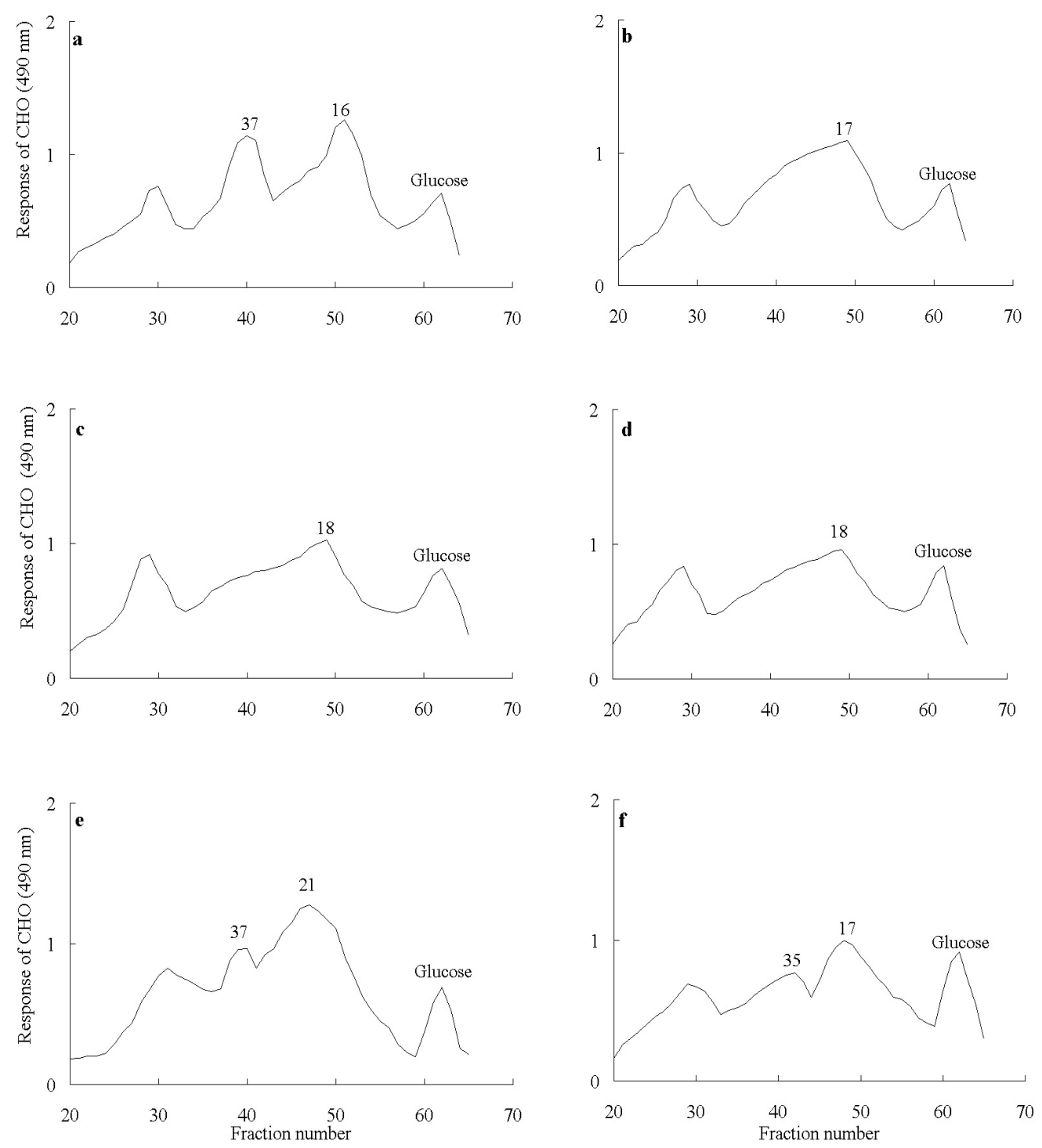

Figure 2 - Elution profiles of cassava and corn isoamylase-debranched starches on Bio-gel P6. a: native cassava; b: cassava + lactic acid + UV; c: commercial fermented cassava starch 1; d: commercial fermented cassava starch 2; e: native corn; f: corn + lactic acid + UV.

\section{Branch Chain Length Distribution of Amylopectin by HPAEC-ENZ-PAD}

Normalized chain length distributions of debranched amylopectins of the native and modified starches determined by HPAEC-ENZPAD are shown in Figure 3 and results are summarized in Table 4. All cassava starch samples showed the first and second peak chain length at DP 12 and 46-47, respectively, whereas the corn starch samples showed the peaks at 13 and 44, respectively. The treatment on the cassava starch resulted an increase in the average chain length from 24.6 to 26.7. There was a decrease in the proportion of short chains (DP 6-12 and DP 13-24) and an increase in the proportion of very long chains ( $D P \geq 37)$. For corn starch samples, there were no significant differences in the branch chain length distributions detected by HPAEC-ENZPAD, indicating that the lactic acid and UV radiation action was more homogeneous on the corn amylopectin. 

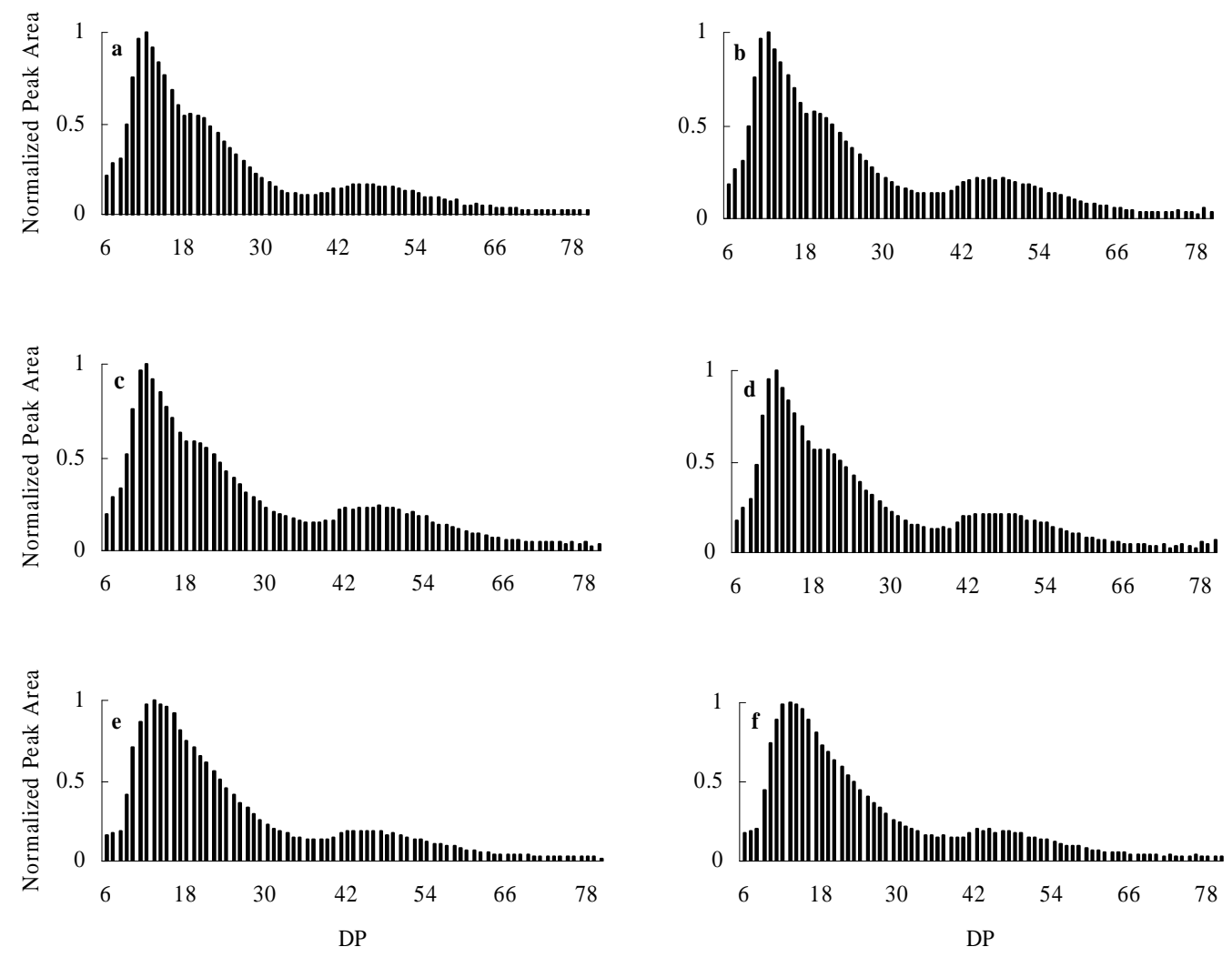

Figure 3 - Branch-chain length distributions of amylopectins analyzed by HPAEC-ENZ-PAD. a: native cassava; b: cassava + lactic acid + UV; c: commercial fermented cassava starch 1; d: commercial fermented cassava starch 2; e: native corn; f: corn + lactic acid + UV.

Table4 - Chain length (CL) distribution of amylopectins samples ${ }^{\text {a }}$.

\begin{tabular}{lccccccc}
\hline & & & & \multicolumn{4}{c}{ Chain length Distribution (\%) } \\
\cline { 5 - 8 } \multicolumn{1}{c}{ Samples } & Peak I & Peak II & CL $^{\mathbf{c}}$ average & DP 6-12 & DP 13-24 & DP 25-36 & DP $\geq \mathbf{3 7}$ \\
\hline Native cassava & 12 & 47 & 24.6 & 23.06 & 41.85 & 14.05 & 21.05 \\
Cassava + lactic acid + UV & 12 & 46 & 26.7 & 20.77 & 39.04 & 14.10 & 26.08 \\
Fermented cassava starch 1 & 12 & 47 & 27.2 & 20.21 & 37.86 & 14.49 & 27.43 \\
Fermented cassava starch 2 & 12 & 46 & 26.8 & 20.50 & 39.07 & 14.34 & 26.07 \\
Native corn & 13 & 44 & 25.1 & 17.99 & 46.03 & 14.76 & 21.21 \\
Corn + lactic acid + UV & 13 & 44 & 25.1 & 17.59 & 46.17 & 15.44 & 20.80 \\
\hline
\end{tabular}

a The values are average of two replicates of each sample.

b Sum of peak-area ratios (\%) of group with degree of polymerization (DP); c CL = Chain Length.

\section{Iodine Affinity and Amylose Content}

Amylose contents of native and modified starches were analyzed by measuring the iodine affinity (Table 5). Native cassava and corn starches showed amylose contents of 20.47 and $25.47 \%$, respectively confirming literature data (Peroni et al., 2006; Srichuwong et al., 2005).
Although the amylose content of native and modified cassava starches were statistically similar, a slight reduction tendency with the treatment was observed, whereas the amylose content of modified corn starch remained unchanged. Nevertheless, from Sepharose CL-2B GPC, it was observed that, after the treatment, the 
amylose peaks of both starches were detected in a higher volume and with a higher blue value response than those from native starches. These results suggested that the treatment resulted in the degradation of both amylose and amylopectin molecules, which were more pronounced for the corn starch, and the amylopectin fractions degraded by the treatment in lower molecular weight molecules could have been eluted at the amylose peak. However, no increase in the iodine affinity for treated samples was observed.

Table 5 - Iodine affinities (IA) and amylose contents of cassava and corn native and modified starches ${ }^{\mathrm{a}}$.

\begin{tabular}{lcc}
\hline Starches & IA & Amylose $^{\mathbf{b}}[\%]$ \\
\hline Native cassava & $3.89^{\mathrm{bc}}$ & 20.47 \\
Cassava + lactic acid + UV & $3.65^{\mathrm{c}}$ & 19.21 \\
Fermented cassava starch 1 & $3.95^{\mathrm{b}}$ & 20.78 \\
Fermented cassava starch 2 & $3.76^{\mathrm{bc}}$ & 19.79 \\
Native corn & $4.84^{\mathrm{a}}$ & 25.47 \\
Corn + lactic acid + UV & $4.79^{\mathrm{a}}$ & 25.21 \\
\hline
\end{tabular}

a Averages of at least two replicates per sample; Values followed by the same letter are not significantly different $(P<0.05)$. b \% Amylose $=[$ IA/ 19.0] $\times 100$.

The acid treatment followed by the ultraviolet radiation provided the baking expansion capacity of cassava starch only. The modified cassava starch showed lower viscosities, greater internal stability and none set back, whereas the viscosities for modified corn starch were almost not detected. There were no significant differences in DSC thermal properties of native and treated starches. Molecular weight of cassava amylopectin was mostly preserved, whereas corn amylopectin was evenly attacked through the granule with the treatment. The B long branch chains of cassava amylopectin, with DP 37, were degraded whereas they remained unchanged for corn amylopectin. The treatment provided a decrease in the proportion of short chains (DP 6-12 and DP 13-24) and an increase in the proportion of very long chains (DP > 37) for cassava amylopectin, whereas there was no significant difference in the branch chain length distribution detected by HPAEC-ENZ-PAD for native and treated corn amylopectin.

\section{ACKNOWLEDGMENTS}

The authors acknowledge the Fundação de Amparo a Pesquisa do Estado de São Paulo, (FAPESP), Brazil for financial support, and Dr. Álvaro Luiz Hattnher for linguistic support.

\section{RESUMO}

Amido de mandioca modificado com ácido lático e radiação ultravioleta antes da secagem artificial têm mostrado boa capacidade de expansão, a exemplo da encontrada para o polvilho azedo. Neste trabalho, os efeitos do ácido lático e radiação UV sobre as características físicoquímicas e estruturais de amidos de mandioca e milho foram investigados. Apenas o amido de mandioca modificado apresentou capacidade de expansão durante o forneamento. Do RVA, redução dos valores de viscosidade, boa estabilidade interna e nenhuma tendência a retrogradação para este amido modificado foi observado. $\mathrm{O}$ amido de milho não apresentou qualquer pico de viscosidade após modificação. Não foram observadas diferenças significativas nas propriedades térmicas, determinadas em DSC, entre os amidos nativos e modificados de ambas as fontes. As moléculas de amilopectina e amilose de ambos os amidos modificados mostraram alguma degradação. $\mathrm{O}$ peso molecular da amilopectina do amido de mandioca foi mais preservado, enquanto a amilopectina do amido de milho foi mais atacada em todo o grânulo. As cadeias ramificadas longas da amilopectina de mandioca, com DP 37, foram degradadas, enquanto as de milho mantiveram-se inalteradas. 


\section{REFERENCES}

Bertolini, A. C.; Mestres, C. and Colonna, P. (2000), Rheological properties of acidified and UV-irradiated starches. Starch/Stärke, 52, 340-344.

Camargo, C.; Colonna, P.; Buléon, A. and RichardMolar, D. (1988), Functional properties of sour cassava (Manioht utilissima) starch: Polvilho azedo. J. Sci. Food Agric., 45, 273-289.

Cereda, M. P. (1983), Padronização para ensaios de qualidade da fécula fermentada (Polvilho azedo). I. Formulacão e preparacão de biscoitos. Bol. Soc. Bras. Ciênc. Tecnol. Alim., 17, 287-295.

Demiate, I. M.; Dupuy, N.; Huvenne, J. P.; Cereda, M. P. and Wosiacki, G. (2000), Relationship between baking behavior of modified cassava starches and chemical structures determined by FTIR spectroscopy. Carbohydr. Polym., 42, 149-158.

Dubois, M.; Gilles, K. A.; Hamilton, J. R.; Roberts, P. A.and Smith, F. (1956), Colorimetric method for determination of sugar and related substances. Anal. Chem., 28, 350-354.

Dufour, D.; Larsonneuer, S.; Alarcon, F.; Brabet, C. and Chuzel, G. (1996), Improving the bread-making potential of cassava sour starch. In-Cassava Flour and Starch: Progress in Research and Development, ed. D. Dufour, G. M. O'Brieu and R. Best. CiradCiat, Nantes, pp. 133-142.

Fannon, J. E.; Hauber, R. J. and BeMiller, J. N. (1992) Surface pores of starch granules. Cereal Chem., 69, 284-288.

Fox, J. T. and Robyt, J. F. (1991), Miniaturization of three carbohydrate analyses using a microsample plate reader. Anal. Biochem., 195, 93-96.

Franco, C. M. L.; Cabral, R. A. F. and Tavares, D. Q. (2002a), Structural and physicochemical characteristics of lintnerized native and sour cassava starches. Starch/Stärke, 54, 469-475.

Franco, C. M. L.; Wong, K. S.; Yoo, S. and Jane, J. (2002b), Structural and functional characteristics of selected soft wheat starches. Cereal Chem., 79, 243248.

French, D. (1984). Organization of starch granule. InStarch: Chemistry and Technology, ed. R. L. Whistler, J. N. BeMiller and E. F. Paschall. Academic Press, New York, pp. 183-247.

Hizukuri, S.; Takeda, Y. and Yasuda, M. (1981), Multibranched nature of amylose and the action of debranching enzymes. Carbohydr. Res., 94, 205-209.

Hizukuri, S. (1986), Polymodal distribution of the chain lengths of amylopectins, and its significance. Carbohydr. Res., 147, 342-347.

Huber, K. C. and BeMiller, J. N. (2000), Channels of maize and sorghum starch granules. Carbohydr. Polym., 41, 269-276.
Jane, J.; Shen, L.; Chen, J.; Lim, S.; Kasemsuwan, T. and Nip, K. (1992), Physical and chemical studies of taro starches and flours. Cereal Chem., 69, 528-535.

Jane, J.; Kasemsuwan, T. and Leas, S. (1994), Anthology of starch granule morphology by scanning electron microscopy. Starch/Stärke, 46, 121-129.

Juliano, B. O. (1971), A simplified assay for milled-rice amylose. Cereal Sci. Today, 16, 334-340.

Kasemsuwan, T.; Jane, J.; Schnable, P.; Stinard, P. and Robertson, D. (1995), Characterization of the dominant mutant amylose-extender (Ae1-5180) maize starch. Cereal Chem., 72, 457-464.

Mestres, C. and Rouau, X. (1997), Influence of natural fermentation and drying conditions on the physicochemical characteristics of cassava starch. $J$. Sci. Food Agric., 74, 147-155.

Mestres, C.; Zakhia, N. and Dufour, D. (1997), Functional and physicochemical properties of sour cassava starch. In-Starch: Structure and Functionality, ed P. J. Frazier, P. Richmond and A. M. Donald. Royal Society Chemistry, London, pp. 42-50.

Mestres, C.; Boungou, O.; Akissoë, N. and Zakhhia, N. (2000), Comparison of the expansion ability of fermented maize flour and cassava starch during baking. J. Sci. Food Agricult., 80, 665-672.

Moorthy, S. N. (1994), Tuber crop starches, Sreekariyam, Thiruvananthapuram, Kerala, India: Central Tuber Crops Research Institute, pp. 1-40.

Peroni, F.H.G.; Rocha, T.S. and Franco, C.M.L. (2006), Some structural and physicochemical characteristics of tuber and root starches. Food Sci. Technol. Int., 12, 505-513.

Plata-Oviedo, M. and Camargo, C. (1998), Effect of acid treatments and drying processes on physicochemical and functional properties of cassava starch. J. Sci. Food Agricult., 77, 103-108.

Song, Y. and Jane, J. (2000), Characterization of barley starches of waxy, normal, and high amylose varieties. Carbohydr. Polym. 41, 365-377.

Srichuwong, S.; Sunarti, T.C.; Mishima, T.; Isono, N., and Hisamatsu, M. (2005), Starches from different botanical sources I: Contribution of amylopectin fine structure to thermal properties and enzyme digestibility. Carbohydr. Polym., 60, 529-538.

Srivastava, H. C.; Harshe, S. N.; Gharia, M. M. and Mudia, G. P. (1970), Physicochemical studies on some starches. Die Stärke, 22, 162-166.

Swinkels, J.J.M. (1985), Composition and properties of commercial native starches. Starch/Stärke, 37, 1-5.

Takeda, Y. and Hizukuri, S. (1987), Structures of rice amylopectins with low and high affinities for iodine. Carbohydr. Res., 168, 79-88.

Wang, Y. -J.; White, P.; Pollak, L. and Jane; J. (1993), Characterization of starch structures of 17 maize endosperm mutant genotypes with Oh43 inbred line background. Cereal Chem., 70, 171-179. 
Westby, A. and Cereda, M.P. (1994), Production of fermented cassava starch (polvilho azedo) in Brazil. Trop. Sci., 34, $203-210$.

Whistler, R. L. and BeMiller, J. N. (1997), Starch. InCarbohydrate Chemistry for Food Scientits. ed. R. L. Whistler and J. N. BeMiller, Eagan Press, Minnesota, pp. 117-151.

Wong, K. S. and Jane, J. (1997), Quantitative analysis of debranched amylopectin by HPAEC-PAD with a postcolumn enzyme reactor. J. Liq. Chrom. Rel. Technol., 20, 297-310.
Vatanasuchart, N.; Naivikul, O.; Charoenrein, S. and Sriroth, K. (2003), Effects of different UV irradiations on properties of cassava starch and biscuit expansion. Kasetsart J. (Nat. Sci.), 37, 334-344.

Received: October 18, 2007; Revised: March 28, 2008; Accepted: July 03, 2009. 